\title{
Description of the Panamá and Iguanita mangrove stands of Bahía Culebra, North Pacific coast of Costa Rica
}

\author{
Jimena Samper-Villarreal ${ }^{1}$, Jorge Cortés ${ }^{1,2} \&$ Catalina Benavides-Varela ${ }^{1,2}$ \\ 1. Centro de Investigación en Ciencias del Mar y Limnología (CIMAR), Ciudad de la Investigación, Universidad de \\ Costa Rica, San Pedro, 11501-2060 San José, Costa Rica; jimena_samper@yahoo.com; jorge.cortes@ucr.ac.cr; \\ tabebuiaguayacan@gmail.com \\ 2. Escuela de Biología, Universidad de Costa Rica, San Pedro, 11501-2060 San José, Costa Rica.
}

Received 28-VII-2011. C Corrected 24-I-2012. Accepted 29-II-2012.

\begin{abstract}
Mangrove forests are abundant and important coastal marine ecosystems that are being impacted by human activity in Costa Rica. There are two mangrove stands (Panamá and Iguanita) in Bahía Culebra, Guanacaste, North Pacific coast of Costa Rica. Their forest structure was determined with the Point-Centered Quarter Method (PCQM) during the dry season (December 2007-March 2008). Eleven transects were established at Panamá mangrove, with a total of 52 points and 208 quadrats. Two transects were established at Iguanita with a total of 16 points and 62 quadrats given access difficulty. Mapping of both stands was done with two georeferenced MASTER CARTA 2005 images. Images were digitized to 1:5000 scale using the following categories: mangrove forest, low density mangrove, no mangrove, transition to dry forest, sand and water. In the area studied at Panamá was 13.7 ha, and 40.8 ha for Iguanita. Panamá is mostly composed of dense mangrove forest (51\% of total study area) and dry forest species (35\% of total study area). A small area (2\%) had dry soil and scarce mangrove trees and the remaining $12 \%$ corresponds to water, sand and other areas without vegetation. At Iguanita, $84 \%$ was dense mangrove, 5\% scarce mangrove trees and the remaining $10 \%$ corresponds to water, sand and other areas without vegetation. Five mangrove species were encountered at Panamá (Avicennia germinans, Avicennia bicolor, Conocarpus erectus, Laguncularia racemosa, and Rhizophora mangle), and three at Iguanita (A. germinans, L. racemosa, and $R$. mangle). Species zonation was similar at both stands; with Rhizophora near water channels and inundated areas, Avicennia frequent in drier areas, and Laguncularia (both stands) and Conocarpus (only Panamá) more frequent near fresh water input. Densities at both stands (Iguanita= 67.2 and Panamá= 8.4 stems/0.1 ha) were lower than reported for the north Pacific of Costa Rica. Complexity index was higher at Iguanita $(\mathrm{CI}=86.5)$ with $R$. mangle dominance, than Panamá $(\mathrm{CI}=1.1)$ with A. germinans dominance. While both stands are in Bahía Culebra, structurally they are very different and seem to be under two different hydrodynamic contexts. Sea level rise related to global climate change might impact both mangrove stands as they would not be able to migrate further inland (given land elevation at the back of Iguanita, and a paved road at Panamá). Given the socio-economic and ecological importance of mangrove habitats, further study and continued conservation efforts of Costa Rican mangroves are needed. Rev. Biol. Trop. 60 (Suppl. 2): 109-120. Epub 2012 April 01.
\end{abstract}

Key words: Mangrove, forest structure, mapping, Eastern Tropical Pacific.

Mangrove forests in the Eastern Pacific extend from the Gulf of California to the northern coast of Peru. While they are abundant on both coasts of the American continent, higher species diversity is found on the Pacific coast (highest in Costa Rica, Panamá and Colombia) than the Caribbean (Spalding et al. 2010). Mangroves also show increased abundance along the Pacific of Costa Rica in comparison with its Caribbean coast, which may be related to a wider tidal range and coastal rugosity in the Pacific (Jiménez \& Soto 1985, Polanía 1993, Cortés \& Werhtmann 2009). Mangroves in the Costa Rican Pacific coast cover approximately 41 002ha of coast line (Pizarro \& Angulo 1993) in 127 individual stands, representing $99 \%$ of 
total mangrove area for the country (ZamoraTrejos 2006). They are divided into three groups based on predominant environmental conditions: a) North Pacific: least developed mangrove stands due to drier climate, higher salinities than oceanic within the mangrove stand and a marked dry season; b) Central Pacific: transition area, with increased precipitation and mangrove development; and c) South Pacific: greater mangrove extension and larger trees, lower salinities than oceanic values within the stand and increased development due to higher precipitation rates (Jiménez \& Soto 1985, Pizarro et al. 2004, Zamora-Trejos \& Cortés 2009).

Despite their abundance and having the benefit of full protection status under Costa Rican legislature (Pizarro et al. 2004), Pacific coast mangroves are not exempt from the various pressures that threaten these habitats. Major pressures include habitat loss and degradation from anthropogenic impacts, such as deforestation for aquaculture and coastal development, hydrodynamic flow alterations, and eutrophication (Valiela et al. 2001, Kathiresan \& Qasim 2005, Feller et al. 2010). Specific pressures in the Pacific coast of Costa Rica consist mainly of deforestation, salt and shrimp pond construction and functioning, destructive fishing practices, carbon and tannin production, land use change into agriculture and coastal infrastructure development particularly for tourism and marinas, among others (Jiménez 1994, Córdoba-Muñoz et al. 1998, ZamoraTrejos \& Cortés 2009).

The importance of mangroves as highly productive coastal habitats that serve critical functions is highly acknowledged and praised, such as their role as nursery areas, land consolidation, sediment trapping, coastal and flood protection, among many others (Hogarth 1999, Kathiresan \& Qasim 2005). Furthermore, along with seagrasses and salt marshes they serve as critical coastal habitats for carbon sequestration, related to climate change mitigation (Sifleet et al. 2011). However, the study of these habitats in the north Pacific of Costa Rica has been scarce, and further knowledge of the presence and characteristics of these habitats is critical (Zamora-Trejos \& Cortés 2009). The present study aims to map and describe the Iguanita and Panamá mangrove stands within Bahía Culebra (Panamá and Iguanita stands), in order to provide further knowledge and understanding of the mangrove habitats in the north Pacific coast of Costa Rica.

\section{METHODOLOGY}

Study sites: Panamá and Iguanita mangrove stands are located in Bahía Culebra (Culebra Bay), North Pacific coast of Costa Rica, within the Área de Conservación Tempisque and Área de Conservación Guanacaste, respectively (SINAC 2010). This region is characterized by a marked dry season in December-April, and wet season May-November. It has mean annual precipitation rates between $1400-1500 \mathrm{~mm} / \mathrm{yr}$, promoting the presence of Tropical Dry Forest (Córdoba-Muñoz et al. 1998, IMN 2010). The North Pacific coast of Costa Rica is a seasonal upwelling area (Alfaro et al. 2012). There is high tourism pressure in the area, particularly with a significant amount of visitors to nearby beaches such as Panamá, Coco and Hermosa (Córdoba-Muñoz et al. 1998; ICT 2010).

Panamá mangrove stand $\left(10^{\circ} 35^{\prime} 25^{\prime \prime} \mathrm{N}\right.$ \& 85³9'56"W; Zamora-Tejos \& Cortés 2009) is linked to the Panamá estuary (IGNCR 1988) behind Panamá Beach (Playa Panamá), and is located near the entrance of the bay. Bravo and Rivera (1998), reported total mangrove area of 60 ha. Iguanita mangrove stand $\left(10^{\circ} 37^{\prime} 05^{\prime \prime} \mathrm{N} \&\right.$ 85³7'07’'W; Zamora-Trejos \& Cortés 2009) is associated with the Iguanita estuary (Quebrada Grande), and has a reported extension of 100ha (Cordoba-Muñoz et al. 1998). It is located in the inner part of the bay, within the Iguanita National Wildlife Refuge (IGNCR 1988, Córdoba-Muñoz et al. 1998, SINAC 2010). Both mangroves are directly linked to freshwater river sources as well as the sea (Fig. $1,2)$, with an estimated average semidiurnal tidal range of $3 \mathrm{~m}$. 

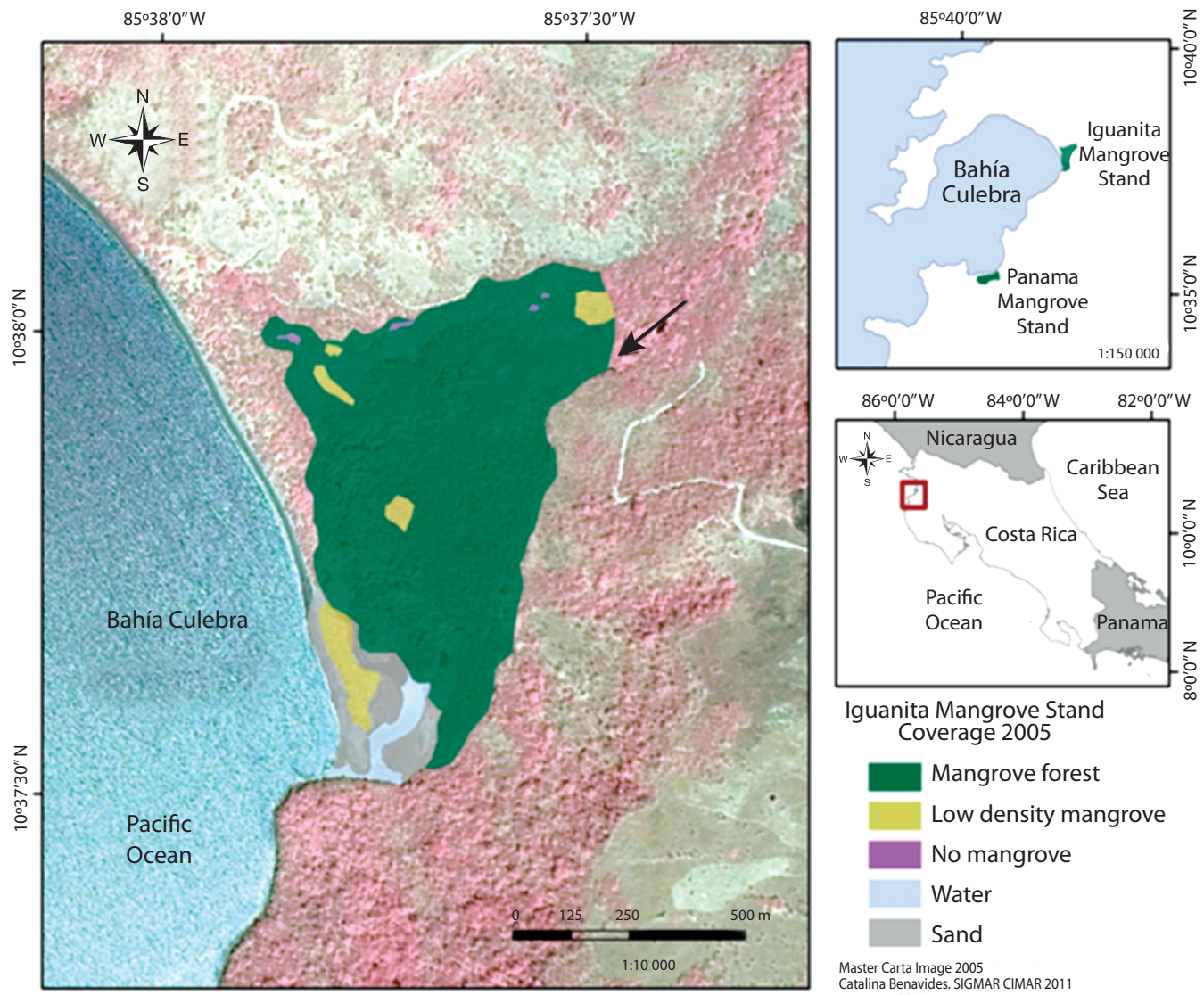

Iguanita Mangrove Stand

Coverage 2005

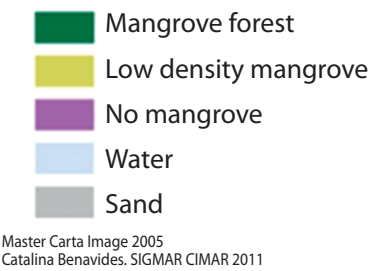

Fig. 1. Mangrove forest at Iguanita, Bahía Culebra, north Pacific coast of Costa Rica. Note: arrow indicates point of river effluence into the stand.

Forest structure: To determine mangrove forest structure the Point-Centered Quarter Method (PCQM) was used (Cintrón \& Novelli 1984). Fieldwork was carried out at low tide intervals on repeated visits to the study sites between December 2007-March 2008 (dry season). At each mangrove, linear transects perpendicular to the coast line were carried out for the width of each stand at intervals of 100m (Panamá) and 250m (Iguanita), and multiple points within each transect were analyzed. Distance to initial point was randomly selected, and in order to avoid analyzing the same tree in more than one point subsequent points were distanced at $20 \mathrm{~m}$ intervals based on observed stand density, therefore avoiding tree overlap. At each point, GPS coordinates were noted when possible and the area surrounding the point was divided into four quadrats. In each quadrat where mangrove trees were present the nearest one with diameter $\geq 2.5 \mathrm{~cm}$ was selected. Distance from the centre point to the tree was noted, as well as species, height, and circumference at breast height (avoiding trunk protuberances) (Pool et al. 1977, Cintrón \& Schaeffer-Novelli 1984).

Total height was determined using a manual HAGA clinometer, adjusting for eye height of observer. When trees were less than $2 \mathrm{~m}$ tall, total height was determined directly by using a measuring tape. Rhizophora mangle circumference in the field was measured directly above 

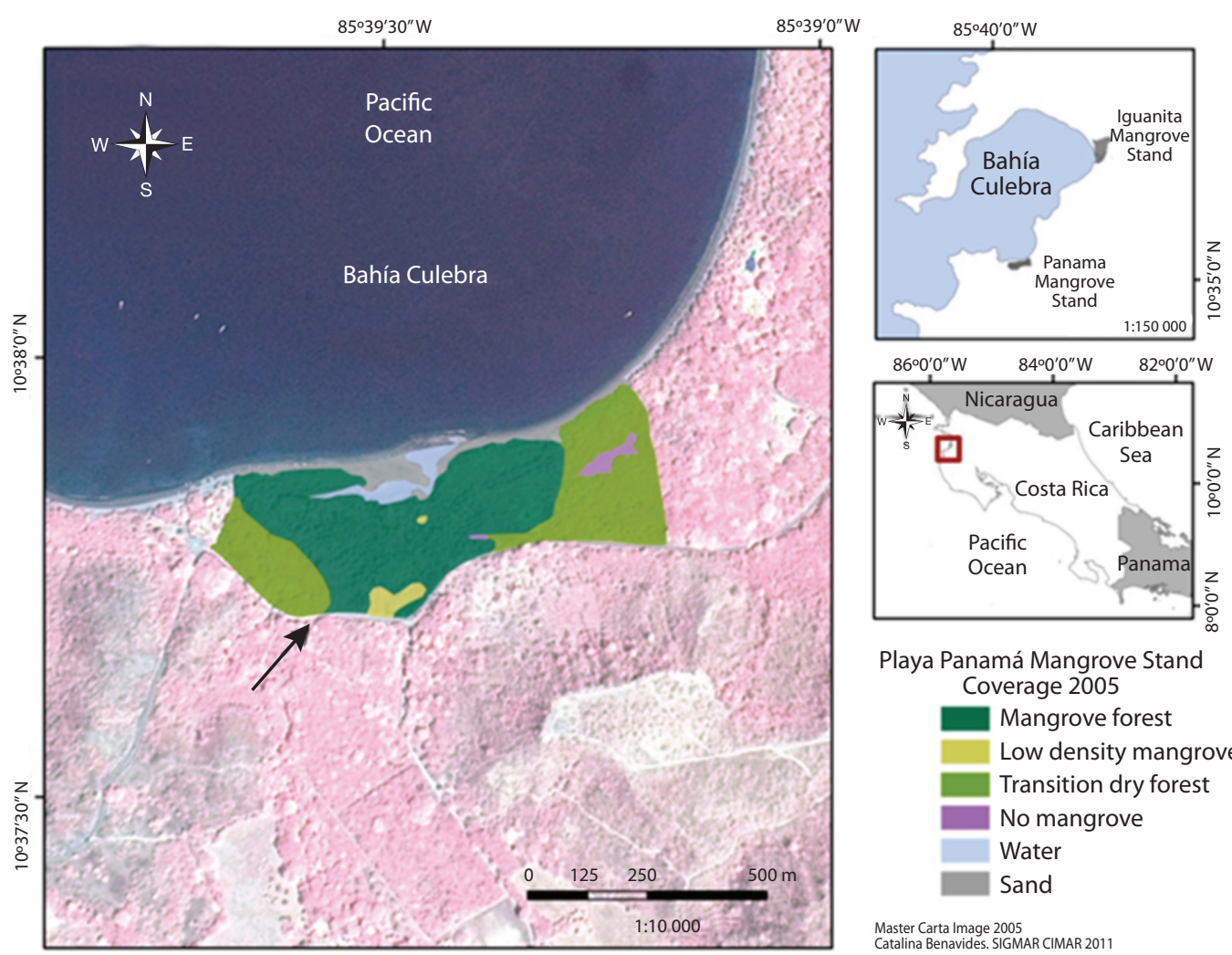

Playa Panamá Mangrove Stand Coverage 2005

Mangrove forest Low density mangrove

Transition dry forest

No mangrove

Water

Sand

Master Carta Image 2005
Catalina Benavides. SIGMAR CIMAR 2011

Fig. 2. Mangrove forest at Playa Panamá, Bahía Culebra, north Pacific coast of Costa Rica. Note: arrow indicates point of river effluence into the stand.

the highest prop root. For other species, when the trunk was evidently subdivided into multiple trunks below breast height, individual measurements were added for a total estimated tree circumference datum. Diameter at breast height $(\mathrm{DBH})$ was determined from field measurements of tree circumference (diameter= circumference/ $\pi$ ). Whenever soil hardness and water availability allowed, a sample of interstitial water was taken at each point (approximately 50ml) digging with a shovel until water presence was evident down to a maximum soil depth of $50 \mathrm{~cm}$. Salinity of each water sample was determined in the laboratory using a handheld refractometer.

A total of 11 transects were carried out at Panamá mangrove, with a total of 52 points and
208 quadrats analyzed. At Iguanita a total of two transects were carried out (one $150 \mathrm{~m}$ and the other $250 \mathrm{~m}$ long), for a total of 16 points and 62 quadrates analyzed. Transects covered the entire Panamá stand extension, while at Iguanita, one transect was carried out at the southern section of the mangrove stand (Transect 1) and the other at the middle of the mangrove (Transect 2), all covering the full width of the stand. Both stands were fully explored with the purpose of edge delimitation and field observations, noting GPS coordinates. Subsequent access to Iguanita proved to be extremely difficult, which is evident in the limited number of points analyzed (16 rather than the recommended minimum of 20 points) (Cintrón \& Schaeffer-Novelli 1984). However, it was 
considered to be sufficient for a preliminary analysis given overall field and image observations, as well as persistent site access difficulty.

Average height and DBH, as well as number of trees per species were determined for each mangrove stand. Number of points and quadrates with each species, total stand density, absolute density, basal area, as well as relative frequency, dominance, density and importance value for each species were calculated following Cintrón \& Schaeffer-Novelli (1984). Stand complexity index was determined as: $\mathrm{CI}=$ [total stand density (stem/0.1ha) $x$ total basal area ( $\mathrm{m}^{2} / 0.1$ ha) $x$ mean tree height $(\mathrm{m}) x$ number of species] $x 10^{-3}$ (Pool et al. 1977, Jiménez \& Soto 1985). Statistical analysis for comparisons between Panamá and Iguanita were carried out by applying t-student and chi squared tests (when possible given unavoidable variation encountered between data collected at each mangrove stand per species, and chi squared tests were corrected for variation in sampled area). Salinity comparisons were done with non-parametric Mann-Whitney U test, all using the statistical program PAST (version 2.01) (Hammer et al. 2001).

Mapping: Mapping of Iguanita and Panamá mangrove stands was carried out using two MASTER CARTA 2005 images, georeferenced with control points taken in the field in 2007 and 2008, and the 2004 digital atlas road layer (ITCR 2004). Costa Rica Lambert Conformal Conic Proyection and Ocotepeque Fundamental Datum were used. To georreference both images a $1^{\text {st }}$ order polynomial transformation was used, with nearest neighbor as the resample type, cell size of $1 \mathrm{~m}$ and georeferencing error determined (Root Mean Square, RMS).

Georeferenced images were digitized to 1:5000 scale using the following categories: a) Dense mangrove, which included only mangrove tree species and evident high canopy cover; b) Low density mangrove, mostly areas with dry soil and scarce mangrove trees (particularly dwarf Avicennia trees); c) Transition to dry forest, with both mangrove and dry forest species; d) No mangrove, specific areas within the stands without vegetation; e) Sand; and f) Water. This classification was made based on field and image observations.

Digitizing was carried out for the study area, incorporating field data. Area of each category was calculated using Spatial Statistics Tools extension of the ArcGIS 9.2 software. Geoereferencing and digitizing was done using the same software. Field data and coordinates were used to develop a GIS database to plot species distribution.

\section{RESULTS}

Mangrove forest structure: At the Panamá mangrove stand total measured distance to center points was $1907 \mathrm{~m}$, a total of 170 mangrove trees were analyzed, and five mangrove species were encountered (Avicennia germinans, Avicennia bicolor, Conocarpus erectus, Laguncularia racemosa, and Rhizophora mangle) (Table 1). Total stand density was 8.4 stems $/ 0.1$ ha, and stand complexity index was 1.1. Relative frequency, dominance and density, as well as the importance value, reflect a clear dominance of $A$. germinans, followed by $L$. racemosa and $C$. erectus; and minimal dominance by the remaining two species encountered (Table 2). While most trees were of considerable height (Table 1), abundant dwarf A. germinans trees $(<1 \mathrm{~m}$ height) were encountered in drier areas of consolidated soil, particularly at the back of the mangrove stand.

At Iguanita, total distance using PCQM was $129.4 \mathrm{~m}, 63$ trees were analyzed, and a total of three species were found (A. germinans, $L$. racemosa and $R$. mangle) (Table 1 ). An A. bicolor tree was observed in the inner and drier part of Iguanita but none were encountered within transects. Total stand density was 67.2stems/0.1ha, and stand complexity index 86.5. Preliminary analysis indicates dominance by $R$. mangle (Table 3 ). Relative frequency, dominance and density from the area studied showed dominance by trees of this species of considerable height (Table 1, 3), reaching up to $40 \mathrm{~m}$ towards the back of the stand near fresh water river input. At Iguanita, L. racemosa was 
TABLE 1

Mean mangrove tree height and diameter at breast height $(\mathrm{DBH})$ per species at both Panamá and Iguanita mangrove stands in Bahía Culebra, north Pacific coast of Costa Rica

\begin{tabular}{|c|c|c|c|c|c|}
\hline Location & $\begin{array}{l}\text { Mean height } \pm \text { se } \\
(\mathrm{m})\end{array}$ & $\begin{array}{c}\text { Min - Max height } \\
(\mathrm{m})\end{array}$ & $\begin{array}{c}\text { Mean } \mathrm{DBH} \pm \mathrm{se} \\
(\mathrm{cm})\end{array}$ & $\begin{array}{c}\text { Min - Max DBH } \\
(\mathrm{cm})\end{array}$ & $\begin{array}{l}\text { Number } \\
\text { of trees }\end{array}$ \\
\hline \multicolumn{6}{|l|}{ Panamá Stand } \\
\hline All species & $11.2 \pm 0.4$ & $2.7-27.8$ & $16.1 \pm 1.2$ & $2.5-125.8$ & 170 \\
\hline \multicolumn{6}{|l|}{ Per species } \\
\hline Avicennia germinans & $11.7 \pm 0.6$ & $2.7-25.5$ & $18.8 \pm 2.0$ & $2.5-125.8$ & 83 \\
\hline Avicennia bicolor & $24.6 \pm 2.2$ & $20.3-27.8$ & $43.7 \pm 11.5$ & $20.7-56.4$ & 3 \\
\hline Conocarpus erectus & $7.5 \pm 0.5$ & $3.0-14.7$ & $10.7 \pm 1.7$ & $2.5-45.2$ & 35 \\
\hline Laguncularia racemosa & $12.5 \pm 0.8$ & $3.0-20.2$ & $14.8 \pm 1.9$ & $3.2-66.9$ & 41 \\
\hline Rhizophora mangle & $10.6 \pm 1.6$ & $4.5-17.8$ & $8.6 \pm 0.8$ & $5.7-12.1$ & 8 \\
\hline \multicolumn{6}{|l|}{ Iguanita Stand } \\
\hline All species & $17.1 \pm 1.3$ & $0.5-40.7$ & $18.1 \pm 1.6$ & $3.2-53.2$ & 63 \\
\hline \multicolumn{6}{|l|}{ Per species } \\
\hline Avicennia germinans & $8.9 \pm 2.2$ & $5.4-13.0$ & $14.3 \pm 2.7$ & $8.9-17.8$ & 3 \\
\hline Laguncularia racemosa & $21.2 \pm 2.7$ & $0.5-40.7$ & $19.7 \pm 2.7$ & $3.5-53.2$ & 23 \\
\hline Rhizophora mangle & $15.3 \pm 1.4$ & $2.0-40.7$ & $17.5 \pm 2.1$ & $3.2-43.0$ & 37 \\
\hline
\end{tabular}

Note. Information for the Iguanita mangrove stand is based on preliminary field analysis.

TABLE 2

Relative and absolute density, relative frequency, basal area, relative cover and importance value per mangrove tree species at the Panamá mangrove stand in Bahía Culebra, north Pacific coast of Costa Rica

\begin{tabular}{lccccrrrr}
$\begin{array}{c}\text { Panamá Stand } \\
\text { Mangrove species }\end{array}$ & $\begin{array}{c}\text { Points } \\
\text { with } \\
\text { species }\end{array}$ & $\begin{array}{c}\text { Absolute } \\
\text { density } \\
\text { (stem/0.1 ha) }\end{array}$ & $\begin{array}{c}\text { Basal } \\
\text { area } \\
\left(\mathrm{m}^{2} / 0.01 \mathrm{ha}\right)\end{array}$ & $\begin{array}{c}\text { Relative } \\
\text { density } \\
(\%)\end{array}$ & $\begin{array}{c}\text { Relative } \\
\text { dominance } \\
(\%)\end{array}$ & $\begin{array}{c}\text { Relative } \\
\text { frequency } \\
(\%)\end{array}$ & $\begin{array}{c}\text { Importance } \\
\text { value }\end{array}$ \\
Avicennia germinans & 31 & 3.35 & 0.178 & 49 & 65 & 39 & 153 \\
Avicennia bicolor & 2 & 0.12 & 0.021 & 2 & 8 & 3 & 12 \\
Conocarpus erectus & 19 & 1.41 & 0.024 & 21 & 9 & 24 & 53 \\
Laguncularia racemosa & 23 & 1.66 & 0.048 & 24 & 18 & 29 & 70 \\
Rhizophora mangle & 5 & 0.32 & 0.002 & 5 & 1 & 6 & 12 \\
Total & 80 & - & 0.273 & 100 & 100 & 100 & 300 \\
\hline
\end{tabular}

TABLE 3

Relative and absolute density, basal area, relative frequency, relative cover and importance value per mangrove tree species at the Iguanita mangrove stand in Bahía Culebra, north Pacific coast of Costa Rica

\begin{tabular}{lccccccc}
$\begin{array}{c}\text { Iguanita Stand } \\
\text { Mangrove species }\end{array}$ & $\begin{array}{c}\text { Points with } \\
\text { species }\end{array}$ & $\begin{array}{c}\text { Absolute } \\
\text { density } \\
\text { (stem/0.1 ha) }\end{array}$ & $\begin{array}{c}\text { Basal area } \\
\left(\mathrm{m}^{2} / 0.01 \text { ha) }\right)\end{array}$ & $\begin{array}{c}\text { Relative } \\
\text { density }(\%)\end{array}$ & $\begin{array}{c}\text { Relative } \\
\text { dominance } \\
(\%)\end{array}$ & $\begin{array}{c}\text { Relative } \\
\text { frequency } \\
(\%)\end{array}$ & $\begin{array}{c}\text { Importance } \\
\text { value }\end{array}$ \\
Avicennia germinans & 2 & 3.15 & 0.05 & 5 & 2 & 10 & 17 \\
Laguncularia racemosa & 8 & 24.16 & 1.03 & 37 & 41 & 38 & 116 \\
Rhizophora mangle & 11 & 38.86 & 1.42 & 59 & 57 & 52 & 168 \\
Total & 21 & - & 2.51 & 100 & 100 & 100 & 300 \\
\hline
\end{tabular}

Note. Information based on preliminary field analysis. 
abundant near the fresh water source for the stand; while A. germinans was only encountered in drier areas of consolidated soil at the back of the mangrove forest, with several dwarf trees present.

Mangrove species zonation followed a similar pattern at both stands; Rhizophora was encountered near channels and inundated areas, Avicennia was frequent in drier areas, and Laguncularia and Conocarpus (latter only encountered at Panamá) were more frequent in areas near fresh water input (Fig. 1, 2). From field observations, it was noted that Panamá had very compact, dry and cracked soil with unvegetated areas with visible surface salt accumulation, soil hydration increased near water channels and decreased drastically away from them. Avicennia pneumatophores were more abundant near water channels and more humid areas. Iguanita had less consolidated soils, more consistently hydrated throughout. Rhizophora trees near water channels had very low DBHs and diminished tree heights. The inward extension of Panamá was mostly limited by a paved road, while the inward extension of Iguanita was mainly limited by topographic variation of land level (increased elevation).

Comparison of shared species within both mangroves is highly restricted by variation in number of trees encountered at each stand, as was the case for A. germinans (Panamá $\mathrm{n}=83$ \& Iguanita $\mathrm{n}=3$ ) (Table 1). Laguncularia trees were significantly taller at Iguanita (Table 1; $\mathrm{t}=3.1, \mathrm{p}<0.05$, Iguanita $\mathrm{n}=22$ \& Panamá $\mathrm{n}=41$ ) but had similar DBH at both sites (Table 1; $\mathrm{t}=1.5, \mathrm{p}>0.05$ ). While Rhizophora tree height showed no significant variation between stands (Table $1 ; \mathrm{t}=1.5, \mathrm{p}>0.05$, Iguanita $\mathrm{n}=37 \&$ Panamá $n=8)$, DBH was significantly higher at Iguanita (Table 1; $\mathrm{t}=3.9, \mathrm{p}<0.001$ ).

Collection of interstitial water samples was only possible at Iguanita, as no interstitial water was available in Panamá at excavated depths, and soil hardness prevented access deeper than $50 \mathrm{~cm}$ during the sampling period. Mean salinity in Transect 1 at Iguanita was $38.2 \pm 3.3 \mathrm{psu}(\mathrm{n}=5$, mean $\pm \mathrm{SD})$, with an average water accessibility depth of $19.0 \pm 17.1 \mathrm{~cm}$.
Transect 2 showed a slight decrease in mean salinity $36.3 \pm 1.5 \mathrm{psu}(\mathrm{n}=6)$, and interstitial water was available at a decreased mean depth $9.2 \pm 2.0 \mathrm{~cm}$. However, no statistical variation in salinity was found between transects (MannWhitney $U=9.5 ; p>0.05$ ) or depth (Mann-Whitney $U=13.5 ; p>0.05$ ). Two samples of channel water within each transect revealed salinities of 36psu (Transect 1) and 35psu (Transect 2).

Mapping: Image georeferencing error was $\mathrm{RMS}=12.1 \mathrm{~m}$ for Iguanita and $\mathrm{RMS}=0.65 \mathrm{~m}$ for Playa Panamá. Variation between locations was due to higher number of field control points for Panamá than for Iguanita. Initial estimation of stand length and width yielded approximate distances of $950 \mathrm{~m}$ x $500 \mathrm{~m}$ for Iguanita, and 940m x 330m for Panamá. Approximate area of mangrove forest (including both high and low mangrove forest density categories) was 13.7ha at Panamá, and 40.8ha at Iguanita (Table 4).

Panamá stand is mostly composed of dense mangrove forest $(51 \%$ of total study area) or dry forest species (35\% of total study area). Small areas had dry soil and scarce mangrove trees $(2 \%)$, as those with no vegetation or covered by water or sand (12\%). At Iguanita $84 \%$ of the total study area corresponded to dense mangrove forest, $5 \%$ had only scarce mangrove trees and $10 \%$ of the area had no vegetation or was covered by sand or water (Table 4 , Figure $1 \& 2$ ). In this case it was not possible to classify the vegetation into mangrove or transition to dry forest, as field data detail did not allow it.

\section{TABLE 4}

Approximate coverage area for Iguanita and Panamá mangrove stands in 2005

\begin{tabular}{lcc}
\multicolumn{1}{c}{ Coverage } & Iguanita (ha) & Panamá (ha) \\
Mangrove & 38.4 & 13.2 \\
Low density mangrove & 2.4 & 0.5 \\
Total mangrove & 40.8 & 13.7 \\
Transition dry forest & $\mathrm{ND}$ & 9.1 \\
No mangrove & 0.1 & 0.4 \\
Water & 1.1 & 0.9 \\
Sand & 3.5 & 1.8 \\
\hline
\end{tabular}

$\mathrm{ND}=$ Not determined 


\section{DISCUSSION}

Previous mangrove research in the north Pacific of Costa Rica has focused mainly on the mangrove stands of Puerto Soley and Santa Rosa, located further North along the coast, with three studies at each site (Zamora-Trejos \& Cortés 2009). The Panamá stand had only been considered in a study related to a species of crab (Ucides occidentalis), where forest structure information was limited to mentioning the presence of three mangrove genera (Cabrera-Peña et al. 1994). Although we present a preliminary analysis and field observations of the Iguanita stand - given logistical difficulties in the field - these findings are relevant given that there are no previous publications of this stand other than a general species list (Córdoba-Muñoz et al. 1998). Results provided by the present study of Iguanita can be used to carry out further related research in this stand and comparisons with more extensive analyses.

All mangrove species encountered in this study have been previously reported for the mangrove vegetation of the North Pacific region of Costa Rica (Soto \& Jiménez 1982, Jiménez \& Soto 1985, Jiménez 1994). The higher number of species encountered at Panamá (five) in relation to Iguanita (three), might be due to a more heterogeneous environment within the Panamá stand from hydrodynamic variations resulting in very arid areas, and more homogenous inundation at Iguanita. However, further study of Iguanita is needed before the presence of other species is discarded. At Panamá, Rhizophora, Avicennia, and Laguncularia had been previously reported by Cabrera-Peña et al. (1994), while C. eructus is a new report for the stand. At Iguanita, previous reported species also included C. erectus, Rhizophora racemosa (Córdoba-Muñoz et al. 1998) (neither encountered in this study), and A. bicolor (Córdoba-Muñoz et al. 1998) (of which only one tree was encountered, located outside of the randomly selected transects). Variation in species previously reported and those found in this study indicates that further analysis of the
Iguanita stand is needed before a definite species listing can be established.

Rhizophora harrisonii and Pelliciera rhizophorae were not encountered at either Panamá or Iguanita, contrary to their reported presence in nearby mangrove stands - R. harrisonii at Puerto Soley (Soto \& Jiménez 1982) and Tamarindo (Pizarro \& Angulo 1993); and P. rhizophorae in Potrero Grande (CórdobaMuñoz et al. 1998), Tamarindo (Pizarro \& Angulo 1993), and Tempisque (Jiménez \& Soto 1985). However, P. rhizophorae is rarely encountered in high salinity mangrove stands such as those present in the north Pacific coast (Jiménez \& Soto 1985). On the other hand, $R$. harrisonii might be a hybrid of $R$. mangle and $R$. racemosa, and accurate species identification in the field may be challenging (Duke et al. 2002). Further detailed study of Rhizophora at both stands, including reproductive morphology and phenology, should be carried out to elucidate species variation.

The complexity index (CI) is a tool for quantitatively comparing forest structural complexity (Pool et al. 1977) which varied between both stands, Iguanita had much higher complexity $(\mathrm{CI}=86.5)$ than Panamá $(\mathrm{CI}=1.1)$. Furthermore, Panamá CI is also lower than those reported for Santa Rosa (CI=4.9) (Pool et al. 1977), and Puerto Soley (CI=17.3) (Jiménez \& Soto 1985), which are the closest studied mangrove areas (further North). Even with data limited to the preliminary analysis, Iguanita is more complex than most mangroves in the area and has values closer to mangrove stands further south (with higher precipitation rates) such as: Tamarindo $(\mathrm{CI}=30.7)$, Pochote $(\mathrm{CI}=30.7)$, Quepos ( $\mathrm{CI}=65.3)$, and Sierpe $(\mathrm{CI}=54.3$, the most developed stand in the Pacific of Costa Rica given significantly increased precipitation rates) (Jiménez \& Soto 1985). Furthermore, including the three additional species reported for Iguanita, but not encountered within transects during this study, would further increase CI to 173.0. Therefore, complete species listings of the entire mangrove stands, not just randomly selected sections, need to be fully developed and a broader study of Iguanita 
carried out before final CI comparisons can be made. Moreover, the different methodologies used for studying the stands (PCQM used in this study vs. parcel and transect methods used in previous studies) may have an impact on results and could affect comparisons among stands (Cintrón \& Schaeffer-Novelli 1984).

Overall, mangrove species zonation followed a similar pattern at both stands, and coincides with previous reports in Costa Rica, with Avicennia species being more tolerant to dry hypersaline conditions, and Rhizophora abundant near hydrated unconsolidated soil and water channels (Soto \& Jiménez 1982, Jiménez \& Soto 1985, Jiménez 1994). Species variation seemed related to freshwater influence (salinity variation) and inundation patterns. Dwarf Avicennia trees, as observed in both stands, have been previously encountered in very dry areas further north (Puerto Soley), where marked seasonal precipitation and lack of tidal flooding for weeks to months leads to increased interstitial salinity, corresponding with decreased tree height, basal area and leaf size (Soto \& Jiménez 1982, Soto \& Corrales 1987). Salinities encountered during this study at Iguanita were not as high as those at Puerto Soley (163psu in dryer areas) (Soto \& Jiménez 1982). However, only humid areas at Iguanita were sampled given limited interstitial water availability. Water shortage frequently coincided with areas dominated by Avicennia and unvegetated salt crusts, which might indicate much higher interstitial water salinities (at greater soil depths than were sampled in this study) as it has been reported that above 60psu Avicennia is the dominant mangrove (Jiménez 1994). Further study of the interstitial water salinity gradient, fresh water input, tidal range and seasonal variations need to be carried out at both stands.

Densities at both stands (Iguanita= 67.2 and Panamá= 8.4stems $/ 0.1$ ha) were lower than those reported for Puerto Soley (170.8stems/0.1ha) (Soto \& Jiménez 1982), and Santa Rosa (105stems/0.1ha) (Pool et al. 1977). This might be related to lower tree height in stands further North due to diminished precipitation, allowing higher densities in shorter forests. Although, higher densities were also found in Barranca (central Pacific) (110stems/0.1ha) a stand dominated by $P$. rhizophorae. Comparing overall stand density among differing species dominance might not be adequate, as well as comparison based on different sampling techniques. A mangrove stand in Osa (south Pacific coast) dominated by $R$. mangle with mean height of $34 \mathrm{~m}$ presented a density of 36stems/0.1ha (Pool et al. 1977), which is intermediate between Iguanita and Panamá, highlighting the great difference encountered between both mangroves within the same bay (Bahía Culebra) and climate.

Lower total densities in Panamá in relation to Iguanita could be indicative of a more mature mangrove stand, as it is considered that as a mangrove forest matures density decreases while tree diameter increases (Cintrón \& Schaeffer-Novelli 1984). However, tree density and diameter comparisons between both stands may not be appropriate given that preliminary analysis of Iguanita showed dominance by Rhizophora within the sampled area, and Panamá was dominated by Avicennia (of which tree height and diameter data was not comparable given critical variation in total trees encountered). Furthermore, Rhizophora tree heights did not vary between stands but diameters were higher at Iguanita, while Laguncularia trees were taller at Iguanita but had similar diameters at both stands. Nonetheless, basal area at both sites (Iguanita=25.1 \& Panamá $=2.7 \mathrm{~m}^{2} / 0.1 \mathrm{ha}$ ) was higher than at Santa Rosa $\left(2.32 \mathrm{~m}^{2} / 0.1 \mathrm{ha}\right)$ (Pool et al. 1977), and Puerto Soley $\left(1.97 \mathrm{~m}^{2} / 0.1 \mathrm{ha}\right)$, which may be due to decreased tree height at this last location (Soto \& Jiménez 1982). Mean and maximum Laguncularia heights at Panamá coincide with those for the North Pacific (12m) (Jiménez \& Soto 1985); yet they are much higher at Iguanita $($ mean $=21.2 \mathrm{~m}$; maximum $=40.7 \mathrm{~m})$. Density variation between studied stands may therefore be due to species density variation (related to hydrodynamic differences) and not stand maturity. Importance value (IV) for Avicennia at Panamá $(51 \%)$ coincides with IV for this 
species at Puerto Soley. However, other important species at Puerto Soley were $R$. mangle and $R$. harrisonii, while at Panamá they were $L$. racemosa and $C$. erectus. This seems to indicate a higher freshwater input at Panamá, as Laguncularia and Conocarpus are more abundant at lower salinities (Soto \& Jiménez 1982). Furthermore, the tallest A. germinans at Puerto Soley were $5 \mathrm{~m}$ (Soto \& Jiménez 1982); while at Panamá they were up to $25 \mathrm{~m}$ (maximum height of $A$. germinans was $25.5 \mathrm{~m}$, and $27.8 \mathrm{~m}$ for A. bicolor). Dominance by $R$. mangle in the area studied at Iguanita, does not coincide with previously reported forest structure for the northern Pacific of dry climate other than at Santa Rosa with Rhizophora being $68 \%$ dominant, yet with a lower mean height of 10m (Pool et. al. 1977). Meanwhile, maximum Rhizophora height at Puerto Soley was $19 \mathrm{~m}$ (Soto \& Jiménez 1982), 18m at Panamá and much higher with $41 \mathrm{~m}$ at Iguanita.

The question remains if comparisons based on preliminary analysis of Iguanita indicating marked forest structure variations between both stands could be related to overall hydrodynamic characteristics of each location, as higher and more frequent inundation at Iguanita, located in the inner part of the Bay, may be leading to Rhizophora dominance. North Pacific mangrove stands are considered to be fringe type mangroves (Pool et al. 1977, Jiménez \& Soto 1985) of high salinity and Avicennia dominance (Jiménez \& Soto 1985), which matched well with the characteristics found at Panamá. However, Iguanita could be more of a riverine type stand, under intense water flow variations and nutrient input, presenting high vegetative development (Cintrón \& SchaefferNovelli 1983) and canopy height (Pool et al. 1977). Given the difference between both stands, with dominance of tall Rhizophora trees at Iguanita, and tall Avicennia trees at Panamá, Bahía Culebra might be a particular transition area between the Central Pacific mangroves (of higher precipitation) and those of more arid climates in the north Pacific region as defined by Jiménez \& Soto (1985).
Mangrove stand area estimates from this study (40.8ha Iguanita \& 13.7ha Panamá) are lower than previous reports of 100ha for Iguanita (Córdoba-Muñoz et al. 1998) and 60ha for Panamá (Bravo \& Rivera 1998). However, the noted higher area at Iguanita in relation to Panamá is maintained. Estimated stand area in the present study was carried out using field coordinates and observations, and defines mangrove area as only containing dense or low density mangrove species. This methodological approach may explain part of the difference in estimated areas from previous reports. However, while it is still considered that both stands have high mangrove vegetation, no doubt related to the overall protection of mangrove forests in Costa Rica, they are still under significant pressure due to tourist facility development and associated negative impacts. Mangroves previously present at the nearby Playas del Coco have now completely disappeared, most likely related to large infrastructure development at this site (per. obs.). Historical image analysis is needed to elucidate if there has been a reduction in mangrove cover at Iguanita and Panamá, and continued conservation of these habitats is critical.

Even though both Iguanita and Panamá mangrove stands are within Culebra Bay, structurally they are very different form one another and seem to be under two different hydrodynamic contexts. Considering that global mean sea level has risen approximately $1-2 \mathrm{~mm} /$ year over the last 100 years (Gornitz 1995, Domingues et al. 2008) and climate change is thought to generate continuous sea level rise in coming years (Titus \& Narayanan 1995), increased inundation might result in mangrove retreat near the shoreline and landward migration (Cohen \& Lara 2003). Unfortunately, both stands studied are limited inland by geographical (increased land elevation), and anthropogenic (roads) barriers that would prevent inward mangrove extension. For this reason, the protection of buffer zones at the back of Costa Rican mangroves is considered of great importance, to increase their chances of survival and conservation. Furthermore, given 
the social, economic and ecological importance of mangrove habitats, further studies at these and other mangroves in the country are urgently needed.

\section{ACKNOWLEDGMENTS}

This project was funded by Ecodesarrollo Papagayo and by the Vicerrectoría de Investigación and CIMAR at the Universidad de Costa Rica. We thank the Escuela de Biología, Universidad de Costa Rica, for equipment loaned. We would like to thank J.A. Sibaja-Cordero for his help with statistical analysis, all those who helped in the field, and three anonymous reviewers whose comments greatly improved this manuscript.

\section{RESUMEN}

Los manglares son abundantes e importantes ecosistemas marino-costeros en Costa Rica pero están siendo afectados por la actividad humana. Se analizó la estructura y cobertura de ambos manglares presentes en Bahía Culebra (Panamá e Iguanita), Guanacaste, Pacífico norte de Costa Rica. Se utilizó el PCQM para estructura durante la época seca entre diciembre 2007 y marzo 2008. Se utilizaron dos imágenes MASTER CARTA 2005 georreferenciadas para mapeo. El área aproximada de bosque de manglar en Panamá fue de 13.7ha; y de 40.8ha en Iguanita. Panamá contiene $51 \%$ de manglar denso en el área de estudio, $35 \%$ bosque seco, $2 \%$ sin vegetación y $12 \%$ de arena o agua. En Iguanita el $84 \%$ del área corresponde a manglar denso, $5 \%$ manglar de baja densidad y $10 \%$ sin cobertura vegetal o era arena o agua. Se hallaron cinco especies de manglar en Panamá (Avicennia germinans, Avicennia bicolor, Conocarpus erectus, Laguncularia racemosa y Rhizophora mangle); y tres en Iguanita (A. germinans, $L$. racemosa y $R$. mangle). En general, la presencia de las especies de manglar siguió un patrón similar en ambos manglares. La densidad total fue menor que en manglares cercanos; y Panamá (8.4tallos/0.1ha) mucho menor que Iguanita (67.2tallos/0.1 ha). El Índice de Complejidad (IC) fue mucho mayor en Iguanita $(\mathrm{IC}=86.5)$, con dominancia de $R$. mangle, que en Panamá ( $\mathrm{IC}=1.1)$, con dominancia marcada de A. germinans. Estructuralmente ambos manglares son muy distintos entre sí y parecen encontrarse en contextos hidrodinámicos diferentes.

Palabras clave: manglares, estructura del bosque, cobertura, Bahía Culebra, Pacífico Tropical del Este.

\section{REFERENCES}

Alfaro, E.J., J. Cortés, J.J. Alvarado, C. Jiménez, A. León, C. Sánchez-Noguera, J. Nivia-Ruiz \& E. RuizCampos. 2012. Clima y variabilidad climática de la temperatura subsuperfical del mar en Bahía Culebra, Guanacaste, Costa Rica. Rev. Biol. Trop. 60 (Suppl. 2): $159-171$.

Bravo, J. \& L. Rivera. 1998. Mapas de Humedales de Costa Rica e Información Complementaria. SINAC, MINAE-UICN, San José, Costa Rica. Escala 1:200 000 .

Cabrera-Peña, J., F. Vives-Jiménez \& Y. Solano-López. 1994. Tamaños y proporción sexual de Ucides occidentalis (Crustacea: Gecarcinidae) en un manglar de Costa Rica. Uniciencia 11: 97-99.

Cintrón, G. \& Y. Schaeffer-Novelli. 1983. Introducción a la ecología del manglar. UNESCO, Montevideo, Uruguay.

Cintrón, G. \& Y. Schaeffer-Novelli. 1984. Methods for studying mangrove structure, p. 91-113. In: S.C. Snedaker \& J.G. Snedaker (eds.). The Mangrove Ecosystem: Research Methods. UNESCO, Paris.

Cohen C.M.L. \& R.J. Lara. 2003. Temporal changes of mangrove vegetation boundaries in Amazonia: Application of GIS and remote sensing. Wetlands Ecol. Manag. 11: 223-231.

Córdoba-Muñoz, R., J.C. Romero-Araya \& N.J. Windevoxhel-Lora. 1998. Inventario de los humedales de Costa Rica. UICN, MINAE, SINAC, Embajada Real de los Países Bajos, San José, Costa Rica.

Cortés, J. \& I.S. Wehrtmann. 2009. Diversity of marine habitats of the Caribbean and Pacific of Costa Rica, p. 1-45. In I.S. Wehrtmann \& J. Cortés (Eds.). Marine Biodiversity of Costa Rica, Central America. Springer + Business Media, Berlin, Germany.

Domingues, C.M., J.A. Church, N.J. White, P.J. Gleckler, S.E. Wijffels, P.M. Barrer \& J.R. Dunn. 2008. Improved estimates of upper-ocean warming and multidecadal sea-level rise. Nature 453: 1090-1093.

Duke, N.C., E. Yuk Ying Lo \& M. Sun. 2002. Global distribution and genetic discontinuities of mangroves - emerging patterns in the evolution of Rhizophora. Trees 16: 65-79.

Feller, I.C., C.E. Lovelock, U. Berger, K.L. McKee, S.B. Joye \& M.C. Ball. 2010. Biocomplexity in mangrove ecosystems. Annu. Rev. Mar. Sci. 2: 395-417. 
Gornitz, V. 1995. Sea-level RSC: a review of recent past and near future trends. Earth Surf. Proc. Land. 20: 7-20.

Hammer, Ø., D.A.T. Harper \& P. Ryan. 2001. PAST: Paleontological Statistics software package for education and data analysis (Version 2.01. May 2010). Palaentol. Electr. 4: 1-9.

Hogarth, P.J. 1999. The Biology of Mangroves. Oxford University Press, Oxford and New York.

IGNCR. 1988. Hoja cartográfica Carrillo Norte 3047 I. Instituto Geográfico de Costa Rica, Ministerio de Transportes, San José, Costa Rica. Edición 3-IGNCR. Escala 1: 50000.

ITCR. 2004. Road Layer, Digital Atlas of Costa Rica. Lambert Conformal Conic Proyection, Ocotepeque Fundamental Datum. 1:200 000. Instituto Tecnológico de Costa Rica. Cartago, Costa Rica.

Jiménez, J.A. 1994. Los manglares del Pacífico Centroamericano. EFUNA, Heredia, Costa Rica.

Jiménez, J.A. \& R. Soto. 1985. Patrones regionales en la estructura y composición florística de los manglares de la Costa Pacífica de Costa Rica. Rev. Biol. Trop. 33: $25-37$.

Kathiresan, K. \& S.Z. Qasim. 2005. Biodiversity of Mangrove Ecosystems. Hindustan Publ., New Delhi, India.

Pizarro, F. \& H. Angulo. 1993. Diagnóstico de los manglares de la costa Pacífica de Costa Rica: Informe para la Comisión Nacional de Manglares. UICN. San José, Costa Rica.

Pizarro, F., L. Piedra, J. Bravo, J. Asch \& C. Asch. 2004. Manual de procedimientos para el manejo de los manglares en Costa Rica. Grupo de Trabajo en Humedales-Costa Rica. Programa Nacional de Humedales. Editorial Fundación UNA, Heredia, Costa Rica.

Polanía, J. 1993. Mangroves of Costa Rica. Part I, p. 129-137. In L.D. Lacerda (Ed.), Conservation and Sustainable Utilization of Mangrove Forests in Latin America and Africa Regions. ITTO/ISME Project PD 114/90 (F), Okinawa, Japan.

Pool, D.J., S.C. Snedaker \& A.E. Lugo. 1977. Structure of mangrove forests in Florida, Puerto Rico, Mexico and Costa Rica. Biotropica 9: 195-212.
Sifleet, S., L. Pendleton \& B.C. Murray. 2011. State of the Science on Coastal Blue Carbon. A Summary for Policy Makers. Nicholas Institute Report, Duke University. Durham, U.S.A.

Soto, R. \& L.F. Corrales. 1987. Variaciones de algunas características foliares de Avicennia germinans (L.) L. en un gradiente climático y de salinidad. Rev. Biol. Trop. 35: 245-256.

Soto, R. \& J.A. Jiménez. 1982. Análisis fisionómico y estructural del manglar de Puerto Soley, La Cruz, Guanacaste, Costa Rica. Rev. Biol. Trop. 30: 161-168.

Spalding, M., M. Kainuma \& L. Collins. 2010. World Atlas of Mangroves. Earthscan. London, United Kingdom.

Titus, J.G. \& V.K. Narayanan. 1995. The Probability of Sea Level Rise. United States Environmental Protection Agency, Washington, DC, USA.

Valiela, I., J.L. Bowen \& J.K. York. 2001. Mangrove forests: one of the world's threatened major tropical environments. BioScience 51: 807-815.

Zamora-Trejos, P. 2006. Manglares, p. 23-39. In: V. Nielsen-Muñoz \& M.A. Quesada-Alpizar (eds). Informe Técnico Ambientes Marino Costeros de Costa Rica. Comisión Interdisciplinaria Marino Costera de la Zona Económica Exclusiva de Costa Rica. CIMAR, CI, TNC, San José, Costa Rica.

Zamora-Trejos, P. \& J. Cortés. 2009. Los manglares de Costa Rica: el Pacífico norte. Rev. Biol. Trop. 57: 473-488.

\section{Internet references}

ICT. 2010. Instituto Costarricense de Turismo. San José, Costa Rica (accessed: 29 April 2010, http://www. visitcostarica.com/ict).

IMN. 2010. Instituto Meteorológico Nacional de Costa Rica. International Airport Daniel Oduber Station in Liberia, Costa Rica (accessed: 29 April 2010, http:// www.imn.ac.cr).

SINAC 2010. Sistema Nacional de Áreas de Conservación, Ministerio de Ambiente Energía y Telecomunicaciones. San José, Costa Rica (accessed: 29 April 2010 http://www.sinac.go.cr). 